\title{
O CONSENTIMENTO INFORMADO E A RESPONSABILIDADE CIVIL DO MÉDICO*
}

\author{
Milton Rodrigues da Silva** \\ Alexandre Torres Petry ${ }^{* * *}$
}

\section{RESUMO}

A presente pesquisa tem como objetivo analisar se a ausência do dever de informar imposto ao médico antes de realizar qualquer tratamento ou procedimento em um paciente, que é condição indispensável do consentimento informado, pode levar a responsabilidade civil do profissional da saúde. Primeiramente será abordada a evolução histórica da relação médico-paciente, que se transformou de uma relação predominantemente paternalista para uma relação contratualista. Na sequência será abordada a definição do princípio da autonomia da vontade e sua importância no fortalecimento da relação entre o médico e seu paciente, sendo abordadas as características e formas como a informação deve ser ofertada ao paciente antes de qualquer procedimento. Em seguida serão estudados o conceito e os requisitos de validade do consentimento informado para que a decisão do paciente possa de fato ser autêntica, informada e

* Artigo apresentado como requisito parcial para obtenção do título de bacharel em Ciências Jurídicas e Sociais pelo Centro Universitário Metodista - IPA, em 2018/2.

** Autor do artigo. Graduando do curso de bacharelado em Direito do Centro Universitário Metodista - IPA.

*** Orientador do artigo. Doutor em Educação pela Universidade Federal do Rio Grande do Sul, Mestre em Direito pela Pontifícia Universidade Católica do Rio Grande do Sul, Especialista em Direito do Consumidor e Direitos Fundamentais pela Universidade Federal do Rio Grande do Sul, Especialista em Direito \& Economia pela Universidade Federal do Rio Grande do Sul e professor da Faculdade de Direito do Centro Universitário Metodista - IPA. 
esclarecida. Por fim, será analisada a relação jurídica médico-paciente bem como a responsabilidade civil do médico decorrente da violação aos deveres éticos e legais relacionados ao consentimento informado, sendo analisada a doutrina e jurisprudência do Tribunal de Justiça do Estado do Rio Grande do Sul.

Palavras-chave: Consentimento informado. Responsabilidade civil. Médico.

\section{THE INFORMED CONSENT AND THE CIVIL LIABILITY OF THE PHYSICIAN}

\section{ABSTRACT}

The current study investigates whether the absence of obligation to enlighten a patient about the risks involved in any medical procedure in advance- indispensable condition of the informed consent- can lead to the civil liability of the health professional. Firstly, the historical evolution of the doctor-patient relationship, which has been transformed from a predominantly paternalistic relationship to a contractualist relationship, will be approached. The second part of the work aims to discuss the definition of the principle of autonomy of will and its importance in strengthening doctor-patient relationship. It will also address the different ways of offering information to the patient before any procedure. The next part of the study will approach the concept and validity requirements of informed consent, so that the patient's decision can in fact be authentic, informed and clarified. The last part issues the legal approach of doctorpatient relationship, as well as the civil liability of the physician due to the violation of ethical and legal duties related to informed consent, analyzing the doctrine and jurisprudence of the Court of Justice of the State of Rio Grande do Sul.

Keywords: Informed consent. Civil responsability. Medical.

\section{INTRODUÇÃO}

Diante da crise na saúde pública brasileira com a consequente sobrecarga de serviço imputada aos profissionais da saúde, a preocupação de se evitar a falta de informações transmitida aos pacientes passou a ser uma constante para aqueles que procuram uma melhor qualidade no atendimento médico.

O aumento significativo, na última década, do número de denúncias e processos por reparação civil envolvendo médicos 
e hospitais ${ }^{1}$, faz com que estes agentes da saúde vivam, sobre o ponto de vista profissional, uma realidade de incertezas e indefinições. Este aumento demonstra uma conscientização cada vez maior da população em busca de qualidade no atendimento que lhe é oferecido.

Nesse sentido, Luciana Roberto ${ }^{2}$ assinala que esta conscientização se deve na medida em que o aumento da informação disponível faz com que as pessoas se tornem mais conscientes e, por consequência, mais exigentes em relação aos serviços médicos, gerando mudanças no comportamento do paciente.

A partir deste dado, ao refletir sobre o tema, outro ponto que deve ser considerado é que devido à essência da atividade médica, esta apresenta riscos que lhe são inerentes. Todo e qualquer procedimento médico, por mais simples que possa ser, enseja um risco que é inerente ao exercício da medicina.

No entender de Facchini Neto $^{3}$, mesmo que o profissional da saúde venha a agir de acordo com os melhores preceitos científicos, utilizando-se das melhores técnicas e adotando os procedimentos mais adequados e recomendados pela ciência médica, alguma consequência não esperada poderá acontecer. O paciente, ao buscar a cura ou a melhoria das condições de sua saúde, quando procura um médico, deve assumir os riscos inerentes a qualquer procedimento ou tratamento que venha a se submeter. Entretanto, para que possa assumir tais riscos, é necessário que tenha sido devidamente esclarecido sobre as possíveis ou potenciais complicações. E é justamente por causa

1 VIEGAS, Cláudia Mara de Almeida Rabelo; MACIEL, Renato Anatólio Lima Horta. A responsabilidade civil dos médicos e hospitais, à luz do direito consumerista. Revista de Direito Privado. São Paulo: Revista dos Tribunais, setembro 2017, v. 81, 2018, p.45.

2 ROBERTO, Luciana Mendes Pereira. Responsabilidade Civil do Profissional de Saúde \& Consentimento Informado. Curitiba: Juruá, 2012, p. 21.

3 FACCHINI NETO, Eugênio. O maior consenso possível - 0 consentimento informado sob o prisma do direito comparado. Revista de Direito Civil Contemporâneo, 2015, p. 954. 
destes efeitos inevitáveis que surge a obrigação de informação do médico.

Nesse contexto, deve ser analisado o direito do paciente de receber as informações pertinentes e o correlato dever do profissional da saúde de fornecê-las, respeitando-se, assim, o direito fundamental à liberdade, constante na legislação pátria, e do qual decorre a chamada autonomia da vontade.

Com o advento da Constituição da República ${ }^{4}$ de 1988, do Código de Defesa do Consumidor ${ }^{5}$ (Lei n. 8.078, de 1990) e do Código Civil ${ }^{6}$ (Lei 10.406 de 2002), ratificou-se o entendimento de que o médico não pode submeter seu paciente a tratamento ou procedimento terapêutico sem antes obter seu consentimento livre e esclarecido, após lhe prestar todas as informações pertinentes ao caso.

Nesse sentido, Vinícius de Negreiros Calado ${ }^{7}$ assinala que o consentimento informado tem como finalidade principal esclarecer ao paciente os riscos, os benefícios, as implicações, sequelas ou complicações, alternativas de diagnóstico e terapêutica, com suas chances de sucesso, bem como os meios e formas de tratamento disponíveis, para que diante dessas informações o paciente possa exercer a sua autonomia e tomar uma decisão livre sobre o procedimento a que será submetido.

Fernandes e Pithan ${ }^{8}$ sobre o tema, tentando desvendar sua finalidade maior e precípua, lecionam:

4 BRASIL. Constituição (1988). Diário Oficial da República Federativa do Brasil, Brasília, DF, 05 de outubro de 1988.

5 BRASIL, Lei no 8078, de 11 de setembro de 1990. Dispõe sobre a proteção do consumidor e dá outras providências. Diário Oficial da República Federativa do Brasil, Brasília,DF, 12 set. 1990.

6 BRASIL, Código Civil. Lei no 10.406, de 10 de janeiro de 2002. Institui o Código Civil. Diário Oficial da República Federativa do Brasil, Brasília, DF, 2002.

7 CALADO, Vinicius de Negreiros. Responsabilidade civil do médico e consentimento informado. Curitiba: Juruá, 2014, p. 316.

8 FERNANDES, Carolina Fernandez; PITHAN,Lívia Haygert. 0 consentimento informado na assistência médica e o contrato de adesão: uma perspectiva jurídica e bioética. Revista HCPA. Porto Alegre, vol. 27, n. 2, 2007, p. 79. 
Consequentemente, pertencerá ao paciente a valoração sobre os procedimentos, riscos, desconfortos e benefícios da terapêutica a que será submetido, através das informações e esclarecimentos necessários fornecidos pelo profissional que o levem a valorar se os riscos que poderá sofrer durante o tratamento valem a aceitação do mesmo.

Contudo, não se deve confundir o dever de prestar as informações pertinentes com aquele sustentado pela medicina defensiva, onde o dever de informar se resume a um documento chamado termo de consentimento informado.

0 dever de informar é mais amplo e consiste em um processo gradual e verbal, onde o médico esclarece ao paciente os riscos, os benefícios, as possibilidades de tratamento, os cuidados e as precauções necessárias, bem como as formas de intervenção.

Nesse sentido, Lívia Pithan ${ }^{9}$ esclarece que de nada adianta o paciente vir a firmar um termo de consentimento informado mal elaborado, com informações vagas, imprecisas ou incompreensíveis, pois estes podem vir a constituir, em um processo judicial, documento probatório de falha no dever de informar. Assim, ocorrendo dano ao paciente e existindo nexo de causalidade entre a falha de informar e o dano, o médico provavelmente será condenado a indenizar.

Desta maneira se justifica a preocupação a respeito do futuro da relação médico-paciente, e a consequente busca de mecanismos internos que se propõem a contribuir com a melhoria desta relação, como por exemplo, a aplicação correta do processo de consentimento informado para os procedimentos médicos.

Ao se estudar a responsabilidade civil médica, podemos perceber que ela compreende a responsabilidade civil direta dos profissionais da medicina, dos hospitais e outros estabelecimentos que prestam serviços de assistência à saúde, inclusive os públicos.

9 PITHAN, Lívia Haygert. O consentimento informado no Poder Judiciário Brasileiro. Porto Alegre: Revista da AMRIGS, jan.-mar. 2012, p. 91. 
O foco deste trabalho está limitado à análise da responsabilidade civil médica quando da relação contratual direta entre o médico e o paciente no que tange a presença ou não de consentimento informado.

\section{A RELAÇÃO MÉDICO-PACIENTE}

\subsection{EVOLUÇÃO HISTÓRICA}

Nem sempre a autonomia da vontade do paciente foi respeitada, conforme assevera Luciana Roberto ${ }^{10}$, pois no passado o médico tinha uma postura paternalista, em que este decidia sozinho, baseado em suas preferências pessoais, o que seria melhor para o seu paciente. Por ser o detentor exclusivo do conhecimento técnico, este se julgava autorizado a tomar as decisões que entendesse serem melhores.

Anota Carlos Ragazzo ${ }^{11}$ que na Grécia antiga o paciente era visto como um incapaz, partindo-se do pressuposto que a doença o impedia de emitir sua vontade, não tendo qualquer participação no processo de decisão médica. Aliás, pelo contrário. Sob a premissa de que essa seria a melhor forma de prover o tratamento, os médicos enxergavam o paciente como uma verdadeira criança, que deveria ser isolada desse processo decisório para o seu próprio bem.

Sebastião Gusmão ${ }^{12}$ assinala que dessa época grega originou-se a visão paternalista do médico em relação ao paciente, pois se o mesmo não era capaz de autodeterminar-se não seria possível sequer levar em consideração a sua emissão de vontade.

10 ROBERTO, Luciana Mendes Pereira. Responsabilidade Civil do Profissional de Saúde \& Consentimento Informado. Curitiba: Juruá, 2012, p. 91.

11 RAGAZZO, Carlos Emanuel Jopert. 0 dever de informar dos médicos e o consentimento informado. Curitiba: Juruá, 2009, p. 40.

12 GUSMÃO, Sebastião. História da medicina: evolução e importância. [S.l.]. 2018. Disponível em: <http://www.museu-emigrantes.org/Hist\%C3\%B3ria-da-medicina.pdf>. Acesso em: 08 jan. 2018. 
A vontade do paciente não era sequer considerada, já que o médico, pela sua formação e experiência, era o único sujeito a quem se reconhecia legitimidade para tomar decisões médicas.

No dizer de Heloisa Helena Barbosa ${ }^{13}$, "desde os tempos de Hipócrates até os nossos dias, busca-se o bem do paciente, ou seja, aquilo que, do ponto de vista da medicina, se considera benéfico para o paciente", sem, contudo, levar em consideração a vontade do próprio paciente. Nesta relação, "atribui-se ao médico o poder de decisão sobre o que é melhor para o paciente". Essa "foi durante longo tempo considerada a relação ética ideal, a despeito de negar ao enfermo sua capacidade de decisão como pessoa adulta". O médico tomava todas as decisões sem o paciente, a quem se dirigia somente para comentar o tratamento com vista a assegurar o seu cumprimento.

Neste mesmo sentido, André Pereira ${ }^{14}$ acrescenta que a relação médico-paciente era do tipo vertical, de forma que o médico desempenhava o papel de tutor e o enfermo o de desvalido. 0 autor, ao buscar as raízes etimológicas da palavra enfermo aduz que a mesma "provém do latim infirmus, ou seja, débil, sem firmeza, não apenas física, mas também moral; de onde resulta que historicamente não fizesse sentido solicitar a sua opinião ou o seu consentimento".

Esse comportamento paternalista não encarava o paciente como um sujeito de direitos, mas apenas como objeto da prestação de serviços médicos.

Esse foi o tipo de relação que predominou desde a origem da medicina até recentemente.

13 BARBOSA, Heloisa Helena. Responsabilidade civil em face das pesquisas em seres humanos: efeitos do consentimento livre e esclarecido.In: MARTINS-COSTA, Judith; MOLLER, Letícia Ludwig (org.). Bioética e Responsabilidade. Rio de Janeiro: Forense, 2009, p. 224.

14 PEREIRA, André Gonçalo Dias. 0 consentimento informado na relação médico-paciente: estudo de Direito Civil. Coimbra: Coimbra, 2004, p. 29. 
Hoje, porém, existe uma forte tendência para que se adote uma postura aberta e transparente, modificando-se o comportamento paternalista, não mais social e eticamente aceito, para um comportamento dialogado onde o médico e o paciente relacionam-se em igualdade, mas cientes de seus diferentes prismas, com compromissos mútuos. Essa é a visão de Vinicius Calado ${ }^{15} \mathrm{e}$ que veio a ratificar a resolução do Conselho Federal de Medicina que aprovou o Código de Ética Médica em 2009.

Nesta relação compartilhada de poder, ao paciente também é assegurado juridicamente o direito de decidir sobre sua saúde, seu corpo e sua vida.

Ainda segundo o autor, a mudança de paradigma para a atualidade é muito nítida, pois o paciente passou de ser meramente um objeto da atuação médica para um paciente senhor de seu destino, recebendo todas as informações pertinentes para que possa assim decidir-se.

André Pereira ${ }^{16}$, ao tratar do assunto, destaca bem essa mudança ao afirmar que:

A autodeterminação nos cuidados de saúde implica, hoje, não só que o paciente consinta ou recuse uma intervenção determinada heteronomamente, mas que tenha todos elementos de análise sobre as possibilidades de tratamento possíveis, assumindo-se como sujeito e como um par, igual na relação.

Desta maneira, no entender de Carlos Ragazzo ${ }^{17}$, o acesso amplo a essas informações reconheceu o cidadão e, mais especificamente, o paciente, como um sujeito de direitos que quer exercer a sua autonomia.

15 CALADO, Vinicius de Negreiros. Responsabilidade civil do médico e consentimento informado. Curitiba: Juruá, 2014, p. 72.

16 PEREIRA, André Gonçalo Dias. 0 consentimento informado na relação médico-paciente: estudo de Direito Civil. Coimbra: Coimbra, 2004, p. 53.

17 RAGAZZO, Carlos Emanuel Jopert. 0 dever de informar dos médicos e o consentimento informado. Curitiba: Juruá, 2009, p. 48. 


\subsection{AUTONOMIA DA VONTADE}

Devido a evolução da medicina e a desmistificação da ideia de o médico ter o conhecimento absoluto de como proceder para obter a cura, ele foi obrigado a respeitar mais as decisões dos pacientes, respeitando a chamada autonomia da vontade.

Segundo Fernanda Borghetti Cantali ${ }^{18}$, seguindo o pensamento de Immanuel Kant, toda pessoa é dotada de autonomia a fim de manifestar a sua vontade de acordo com sua conveniência, ou seja, é o direito de fazer suas próprias escolhas sem imposições externas. Esta autonomia está subordinada à razão e ao exercício da vontade do ser humano, inerentes ao princípio da dignidade da pessoa humana. Envolve a denominada autodeterminação que é o direito da pessoa de decidir os rumos da própria vida e de se desenvolver livremente.

A Constituição Federal tipifica como princípio basilar de nosso ordenamento jurídico a dignidade da pessoa humana, e essa só será devidamente concedida com o exercício da autonomia da vontade pelo paciente.

As previsões inseridas no vigente Código de Ética Médica ${ }^{19}$, editado pela Resolução do Conselho Federal de Medicina (CFM) no 1931/2009 e em vigor a partir de 2010, aludem o dever do médico de informar e de respeitar a autonomia da vontade do paciente em mais de uma oportunidade.

De fato, no Capítulo IV, intitulado "Direitos Humanos", estabelece-se que:

É vedado ao médico:

Art. 22. Deixar de obter consentimento do paciente ou de seu representante legal após esclarecê-lo sobre

18 CANTALI, Fernanda Borghetti. Direitos da Personalidade - disponibilidade relativa, autonomia privada e dignidade humana. Porto Alegre: Livraria do Advogado, 2009, p. 202.

19 VIEIRA, Jair Lot. Código de Ética Médica. 3. ed. Rio de Janeiro: edipro, 2014 , p. 24 e 25. 
o procedimento a ser realizado, salvo em caso de risco iminente de morte.

Art. 24. Deixar de garantir ao paciente o exercício do direito de decidir livremente sobre sua pessoa ou seu bem-estar, bem como exercer sua autoridade para limitá-lo.

Já no Capítulo V, denominado "Relação com Pacientes e Familiares", o artigo 31afirma que é vedado ao médico desrespeitar o direito do paciente ou de seu representante legal de decidir livremente sobre a execução de práticas diagnósticas ou terapêuticas, salvo em caso de iminente risco de morte.

Assim, de forma clara, como se vê, tais normas preveem o dever de informar que incumbe ao médico, vedam o exercício da medicina sem a obtenção do consentimento livre e esclarecido do paciente e assinalam as exceções a tal dever.

Segundo Vinicius Calado ${ }^{20}$, a autonomia da vontade está presente no artigo 15 do Código Civil Brasileiro ao estabelecer que ninguém pode ser constrangido a submeter-se, com risco de vida, a tratamento médico ou a intervenção cirúrgica.

Há, portanto, a necessidade de que a pessoa autorize os procedimentos a serem realizados em seu corpo.

Nesta mesma linha, o Código de Defesa do Consumidor ${ }^{21}$ exige a prestação de esclarecimento em seus diversos artigos, destacando-se o artigo 14, que impõe ao fornecedor de serviços a responsabilidade por prestar informações insuficientes ouinadequadas.

Se de um lado da relação jurídica a informação é um direito básico do paciente, do outro lado desta relação deve existir o correspondente dever do médico de fornecer tais informações.

20 CALADO, Vinicius de Negreiros. Responsabilidade civil do médico e consentimento informado. Curitiba: Juruá, 2014, p. 80.

21 BRASIL, Lei no 8078, de 11 de setembro de 1990. Dispõe sobre a proteção do consumidor e dá outras providências. Diário Oficial da República Federativa do Brasil, Brasília, DF, 12 set. 1990. 
Assim sendo, na visão de Facchini Neto e Luciana Eick ${ }^{22}$, o médico só poderá agir sem o consentimento do paciente ante a uma emergência ou fato superveniente ocorrido em meio a um procedimento, pois a interrupção da intervenção poderia trazer perigo de vida ao paciente.

Não pode o médico, em um cenário em que o paciente está na iminência de risco de vida causado por uma enfermidade, deixar de atuar somente porque não há possibilidade de se obter o prévio consentimento. 0 médico tem o dever legal e moral de agir para salvar a vida do paciente, sob pena de omissão e posterior responsabilização.

Nesse sentido, já decidiu o Tribunal de Justiça do Estado do Rio Grande do Sul (TJRS) que, em caso de risco de vida do paciente, não há que se falar em consentimento informado:

\begin{abstract}
RESPONSABILIDADE CIVIL. AÇÃO INDENIZATÓRIA. ERRO MÉDICO NÃO EVIDENCIADO. DEVER DE INDENIZAR INOCORRENTE. - Caso em que o familiar da parte autora foi internado na casa de saúde requerida HOSPITAL CONCEIÇÃO com quadro inicial de diarreia e gastroenterite de origem infecciosa, vindo a evoluir negativamente apresentando trombose venosa profunda com consequente hemorragia cerebral. Necessidade de transferência para outro nosocômio - HOSPITAL CRISTO REDENTOR pertencente ao grupo hospitalar, por ser mais especializado na área médica - Inexistência de nexo de causalidade entre a morte do paciente com os procedimentos médicos adotados pela parte ré. Perícia neurológica que apontou evolução desfavorável e êxito legal inerentes à gravidade do evento hemorrágico. Comorbidades pessoais do próprio paciente que contribuíram para o evento morte Dever de informação quanto à remoção para outra
\end{abstract}

22 FACCHINI NETO, Eugênio; EICK, Luciana Gemelli. Responsabilidade civil do médico pela falha no dever de informação, à luz do princípio da boa-fé objetiva. Revista da AJURIS, 2016, v. 42, n. 138, p. 61. 
casa de saúde que se mostrou descabido em razão da própria evolução rápida e inesperada do quadro clínico do paciente, tratando-se de procedimento de urgência. Direito à vida que se sobrepõe à necessidade de prévio consentimento informado. Esclarecimento da causa da morte que dependia de uma análise mais profunda, com a realização de exame de necropsia - Responsabilidade civil não evidenciada. Dever de indenizar inocorrente. Sentença de improcedência mantida. NEGARAM PROVIMENTO À APELAÇÃO. UNÂNIME. (Apelação Cível № 70074363060, Décima Câmara Cível, Tribunal de Justiça do RS, Relator: Jorge Alberto Schreiner Pestana, Julgado em 01/03/2018).

Dessa maneira, o dever de informar do médico e a consequente obtenção do consentimento informado encontram amparo legal, e possui como função principal permitir ao paciente fazer conscientemente sua opção, com responsabilidade, conhecendo os riscos e consequências, respeitando assim a sua autonomia da vontade.

\section{CONSENTIMENTO INFORMADO}

Ao buscarmos a definição de consentimento informado no Dicionário Houaiss da Língua Portuguesa, edição de 2001, encontramos:

[...] ato ou efeito de consentir. 1 - Manifestação a que (alguém) faça (algo); permissão, licença. 2 - Manifestação de que se aprova (algo); anuência, aquiescência, concordância. 3 - Tolerância, condescendência. 4- uniformidade de opiniões; concordância de declarações. Acordo de vontades das partes para se alcançar um objetivo comum ${ }^{23}$.

23 HOUAISS, Antônio; VILLAR, Mauro; DE MELLO FRANCO, Francisco Manoel.

Dicionário Houaiss da Língua Portuguesa. 2001, p. 76. 
Podemos perceber, a partir dos conceitos explanados até o momento, que o consentimento informado se caracteriza como sendo uma expressão da vontade, onde o paciente demonstra que compreende o tratamento a ser realizado, seus riscos e possibilidades e consente com sua efetivação.

Entretanto, conforme assevera Carlos Ragazzo ${ }^{24}$, não basta que o paciente consinta o tratamento ou procedimento médico que lhe foi indicado. Para que a decisão do paciente possa de fato ser autêntica, informada e esclarecida, refletindo assim o exercício da autonomia da vontade, é indispensável que sejam cumpridos os requisitos necessários para a validade do ato autônomo, quais sejam, a capacidade, a informação e a voluntariedade.

0 requisito da capacidade diz respeito à aptidão do paciente para compreender a situação que enfrenta, avaliando os riscos e benefícios envolvidos no tratamento ou procedimento proposto.

Já o requisito da informação se refere à quais informações são relevantes para o paciente e a maneira como essas informações são transmitidas.

Por último, o requisito da voluntariedade trata do reconhecimento da soberania da vontade do paciente, a qual deve ser livre de qualquer manipulação, refletindo exatamente as suas razões e emoções pessoais.

Dessa maneira, o consentimento informado possui como requisitos de validade esses três elementos formadores específicos, sem os quais, ou na ausência de um deles, o instituto sob exame não fornecerá os efeitos pretendidos.

\subsection{REQUISITOS DE VALIDADE}

Como visto acima, para que os efeitos jurídicos da obtenção do consentimento informado não sejam frustrados, este deve estar revestido de certas prerrogativas para ter existência, ser válido e apto para produzir seus efeitos.

24 RAGAZZO, Carlos Emanuel Jopert. 0 dever de informar dos médicos e o consentimento informado. Curitiba: Juruá, 2009, p. 89. 
O primeiro requisito de validade é a capacidade; o segundo é a informação, e o terceiro e último é a voluntariedade. Estes três elementos do consentimento informado e suas peculiaridades serão agora examinados.

\subsubsection{Capacidade}

A capacidade civil é entendida em nosso ordenamento jurídico como a capacidade plena da pessoa reger sua vida, seus bens e sua aptidão para os atos da vida civil.

$\mathrm{Na}$ visão de Carlos Ragazzo ${ }^{25}$, a capacidade do paciente é essencial para a validade do consentimento informado. Os critérios de capacidade civil dispostos na legislação, em especial no Código Civil, servem como bons indicadores de aptidão para tomar decisões médicas. Contudo, conclui o autor, somente a capacidade civil não serve como requisito único para avaliar se determinado consentimento foi válido. Isso porque a capacidade tem essência primordialmente jurídica (aptidão para praticar atos da vida civil), ao passo que a competência, por ser um conceito clínico, mais amplo, quando aferida por um profissional da saúde, demonstra a real condição do paciente em consentir.

A conjugação desses dois critérios, no entender do autor, atestam o requisito de validade quanto a capacidade do paciente no ato do consentimento.

Esta condição é essencial para o objetivo do consentimento informado, pois o indivíduo precisa realmente entender o seu diagnóstico, suas possibilidades terapêuticas, os riscos, as possíveis complicações, entre outros aspectos ligados ao seu quadro clínico.

Aprofundando-se sobre o tema, André Pereira ${ }^{26}$ entende que ao avaliar a capacidade cognitiva de um paciente, o médico pode

25 RAGAZZO, Carlos Emanuel Jopert. 0 dever de informar dos médicos e o consentimento informado. Curitiba: Juruá, 2009, p. 90.

26 PEREIRA, André Gonçalo Dias. 0 consentimento informado na relação médico-paciente: estudo de Direito Civil. Coimbra: Coimbra, 2004, p. 475. 
começar a lhe prestar as informações, porém, à medida que vai estabelecendo este contato vai-se apercebendo da real capacidade de entendimento e decisão do doente, podendo, ao final, vir a considerá-lo incapaz.

Assim sendo, em regra, a pessoa com capacidade civil plena será capaz para consentir, dependendo da situação concreta do paciente.

\subsubsection{Informação}

Entre os requisitos de validade do consentimento informado, talvez a informação seja um dos mais importantes, conforme assevera Carlos Alberto Silva ${ }^{27}$, ao afirmar que esta deve ser clara, objetiva e em linguagem compatível com o receptor.

Em relação ao conteúdo da informação, o Código de Ética Médica $^{28}$ assinala em seu capítulo V, artigo 34 :

\section{É vedado ao médico:}

Art.34. Deixar de informar ao paciente o diagnóstico, o prognóstico, os riscos e os objetivos do tratamento, salvo quando a comunicação direta possa lhe provocar dano, devendo, nesse caso, fazer a comunicação a seu representante legal.

Ou seja, a informação deve ser clara e objetiva no sentido de informar o paciente o diagnóstico, prognóstico, riscos e objetivos do tratamento ou procedimento.

É justamente com esse cenário em mente que Gustavo Borges ${ }^{29}$ escreve:

27 SILVA, Carlos Alberto. O consentimento informado e a responsabilidade civil do médico. Revista do Tribunal Regional Federal 1a Região, Brasília, v. 15, no 5, maio, 2003, p.33.

28 VIEIRA, Jair Lot. Código de Ética Médica. 3. ed. Rio de Janeiro: edipro, 2014, p. 25 .

29 BORGES, Gustavo. Erro médico e a falha no dever de informação: a proteção do consumidor. Revista de Direito do Consumidor, vol. 102, ano 24. São Paulo: Revista dos Tribunais, nov.- dez. 2015, p. 461. 
Tais informações acerca do estado de saúde devem ser fornecidas aos pacientes de forma clara, completa e sempre adaptadas à individualidade de cada paciente para o possível e ampliado alcance da compreensão, dentro de suas condições pessoais. É de se esperar do médico dedicação didática ao explicar, detalhadamente, ao paciente, tanto os limites técnicos, quanto os riscos operatórios para provê-los dos subsídios necessários para a sua tomada de decisão autônoma e esclarecida.

Ao debruçar-se sobre o assunto, André Pereira ${ }^{30}$ assinala que para poder prestar o consentimento, é necessário que a informação que será transmitida pelo médico ao paciente seja compreensível, ou seja, deve operar numa lógica de simplicidade, verdade e suficiência. Ainda segundo o autor, o médico deve procurar respeitar o sistema de valores do paciente e estabelecer um diálogo que acompanhe as capacidades intelectuais e culturais dele, devendo usar uma linguagem acessível, não técnica.

Robustecendo a assertiva do autor antes mencionado, Antônio Efing e Mariana Neves ${ }^{31}$ chegam a afirmar que o médico deve observar a personalidade do paciente, sua capacidade de compreensão, suas concepções éticas, morais, religiosas, culturais, filosóficas, entre outras. A informação que para uma pessoa pode ser considerada desprezível, para outro pode ser fundamental, cabendo ao médico analisar cada paciente.

Assim sendo, para que o paciente possa consentir, se faz necessário e imprescindível que o médico lhe esclareça de forma adequada e compreensível, respeitando o nível sociocultural de cada paciente.

30 PEREIRA, André Gonçalo Dias. O consentimento informado na relação médico-paciente: estudo de Direito Civil. Coimbra: Coimbra, 2004, p. 457.

31 EFING, Antônio Carlos; NEVES, Mariana Moreira. Consentimento livre e esclarecido: responsabilidade civil do médico pelo descumprimento do dever de informar. Revista da Faculdade de Direito da UFMG, 2015, n. 65, p. 73. 


\title{
3.1.3 Voluntariedade
}

0 terceiro requisito de validade para a prestação do consentimento informado é a voluntariedade.

Carlos Ragazzo ${ }^{32}$ assinala que o consentimento será considerado válido quando haja sido livremente prestado, ou seja, deve ser obtido de forma voluntária, sem qualquer coação ou vício da vontade. Esta voluntariedade pode ser tratada como uma pré-condição do instituto em questão e definida como a ausência de coação ou ameaça - ou suspeita de ameaça - exercida pelo médico.

No entender de Fernandes e Pithan ${ }^{33}$ :

\begin{abstract}
Quanto à voluntariedade, cabe explicar que a mesma se dá ao longo da tomada de decisões por uma pessoa, com a minimização de qualquer forma de constrangimento ou coerção. A vulnerabilidade do paciente, entendida de forma dinâmica, acaba por influenciar em seu consentimento.
\end{abstract}

Sendo assim, não basta aferir a mera capacidade ou discernimento do paciente, ou se a informação transmitida foi adequada ao entendimento do paciente, sendo também fundamental averiguar se o consentimento é prestado de forma livre e espontânea, isto é, isento de qualquer influência.

Carlos Alberto Silva ${ }^{34}$, ao se manifestar sobre a possibilidade de influenciar a vontade do paciente, identifica três hipóteses mais comuns: a persuasão, a coação e a manipulação propriamente dita.

A persuasão seria um processo em que o paciente é subme-

32 RAGAZZO, Carlos Emanuel Jopert. 0 dever de informar dos médicos e o consentimento informado. Curitiba: Juruá, 2009, p. 96.

33 FERNANDES, Carolina Fernandez; PITHAN,Livia Haygert. 0 consentimento informado na assistência médica e o contrato de adesão: uma perspectiva jurídica e bioética. Revista HCPA. Porto Alegre, vol. 27, n. 2, 2007, p. 79.

34 SILVA, Carlos Alberto. 0 consentimento informado e a responsabilidade civil do médico. Revista do Tribunal Regional Federal da 1a Região. Distrito Federal: 2003, no5, p. 34. 
tido de maneira que não lhe é dada a possibilidade de efetuar nenhum tipo de escolha.

A coação é caracterizada principalmente pela ameaça, quer seja da forma implícita ou explícita.

E por último a manipulação, onde o médico, por ser o possuidor dos conhecimentos técnicos, fica capacitado a dar determinada informação ao paciente de modo que o leve a tomar somente uma única decisão.

Desta maneira, conclui Carlos Ragazzo ${ }^{35}$, sem qualquer desses três elementos (capacidade, voluntariedade e compreensão) os efeitos jurídicos da obtenção do consentimento informado serão frustrados.

\section{RESPONSABILIDADE CIVIL}

Importa a esse estudo, delinear a responsabilidade civil e estabelecer a natureza jurídica daquela que nasce a partir da relação privada médico-paciente.

\subsection{NATUREZA JURÍDICA DA RELAÇÃO MÉDICO-PACIENTE}

Por representar a manifestação de uma vontade humana, o consentimento informado situa-se no campo dos atos jurídicos, cujo conceito vem definido expressamente no Código Civil, ao afirmar que nenhum procedimento médico pode ser realizado sem prévia autorização.

A doutrina ${ }^{36}$ tem tratado majoritariamente que a relação jurídica médico-paciente é, via de regra, de natureza contratual, sendo o dever de informar decorrente do princípio da boa-fé objetiva, que pauta as relações jurídicas. Ainda segundo os autores, durante uma relação contratual, tem-se que a informação é um

35 RAGAZZO, Carlos Emanuel Jopert. 0 dever de informar dos médicos e o consentimento informado. Curitiba: Juruá, 2009, p. 89.

36 Nesse sentido MIRANDA, Pontes de. Tratado de Direito Privado. Rio de Janeiro: Borsoi, 1966. T. LIII, p. 439, e DIAS, José de Aguiar. Da Responsabilidade Civil. Rio de Janeiro: Lumen Juris, 2012, p. 277. 
dos deveres anexos da boa-fé objetiva, cabendo a todas as partes que compõem esta relação informar as outras sobre o necessário.

Paulo de Tarso Sanseverino ${ }^{37}$ ao concordar com a opinião da doutrina majoritária, assinala:

\begin{abstract}
Encontra-se hoje superada a discussão em torno da natureza contratual da responsabilidade de determinados profissionais liberais como médicos, cirurgiões, farmacêuticos e dentistas, que decorria da inserção da regra do art. 951 do Código Civil de 2002 (art. 1.545 do CC/1916) entre, as modalidades de responsabilidade aquiliana. 0 entendimento doutrinário dominante acerca da responsabilidade desses profissionais é, em regra, efetivamente, contratual.
\end{abstract}

O princípio da boa-fé é um dos princípios básicos do direto brasileiro, estando elencado em vários artigos do Código Civil, em especial nos artigos 113 e 422, ao impor às partes que resguardem, tanto na conclusão quanto na execução de um contrato, os princípios da probidade e da boa-fé.

Paulo Lôbo ${ }^{38}$, nesse passo, subministra proveitosa observação, ao afirmar que o direito à informação é um direito fundamental consagrado no artigo 5ํㅜ XIV da Constituição Federal e decorrente do princípio da boa-fé objetiva, tendo por significado a representação de um comportamento cuja conduta é matizada na lealdade, na correção, na probidade, na confiança e na ausência de intenção lesiva ou prejudicial.

No magistério de Sergio Cavalieri ${ }^{39}$, o princípio da boa-fé objetiva se traduz na cooperação, na lealdade, na transparência,

37 SANSEVERINO, Paulo de Tarso.Responsabilidade civil no Código do Consumidor e a defesa do fornecedor. São Paulo: Saraiva, 2010, p. 199.

38 LÔBO, Paulo Luiz Netto. A informação como direito fundamental do consumidor. Revista de Direito do Consumidor, no 37, jan. - mar. 2001, p. 65. 39 CAVALIERI FILHO, Sérgio. Programa de responsabilidade civil. 11 ed. São Paulo: Atlas, 2014, p. 392. 
na correção, na probidade e na confiança que devem existir na relação médico-paciente.

Ao debruçar-se sobre o assunto Antonio Efing e Mariana Neves $^{40}$ asseveram:

O dever de informar deriva do princípio da boa-fé objetiva em matéria contratual, positivado no artigo 422 do Código Civil. Uma vez violado este dever, caracterizar-se-á espécie de inadimplemento contratual. Além disso, os incisos XIV, XXXIII e LXXII, do artigo 5ำ da Constituição Federal, assegura a todos o direito à informação. Contudo, em se tratando de relação médico-paciente, o direito à informação ultrapassa a ideia de boa-fé, apresentando-se como um desdobramento da autonomia e da dignidade da pessoa humana.

Luciana Roberto ${ }^{41}$, comungando do entendimento supratranscrito, afirma que a interpretação contratual, nos dias de hoje, exige novos princípios norteadores por parte do julgador. Além daqueles já aplicados, como a autonomia da vontade, a força obrigatória dos contratos, a autonomia privada, a relatividade, a supremacia da ordem pública, o consensualismo e a possibilidade de revisão, existe uma outra principiologia que necessariamente deve ser somada na interpretação dos contratos, aquela representada pela socialidade, pela eticidade (aqui a caracterização da boa-fé objetiva) e pela operabilidade do Direito.

0 Código de Defesa do Consumidor também se refere à boa-fé em seu artigo 4ํㅡㄴ, III, ao estabelecer o dever de harmonia dos interesses dos participantes das relações de consumo, sempre com base na boa-fé e equilíbrio nas relações entre consumidores e fornecedores.

40 EFING, Antônio Carlos; NEVES, Mariana Moreira. Consentimento livre e esclarecido: responsabilidade civil do médico pelo descumprimento do dever de informar. Revista da Faculdade de Direito da UFMG, 2015, n. 65, p. 72.

41 ROBERTO, Luciana Mendes Pereira. Responsabilidade Civil do Profissional de Saúde \& Consentimento Informado. Curitiba: Juruá, 2012, p. 178. 
Trata-se do dever de cooperação, que, segundo Cláudia Lima Marques ${ }^{42}$, é um dever que leva cada contratante a fazer o que estiver ao seu alcance para que todas as partes alcancem seus objetivos fixados quando da contratação. Assim, segundo a autora, o fato de não se observar o dever de informar por uma das partes, enseja o inadimplemento contratual, e, portanto, atribui responsabilidade civil ao médico quando, da ausência desta informação, sobrevierem danos ao paciente, por violação ao princípio da boa-fé objetiva.

É também essa a concepção de Bruno Miragem ${ }^{43}$ quando afirma que em razão da eficácia que se reconhece à boa-fé objetiva como fonte autônoma de deveres jurídicos, sua violação acarreta um dever de indenizar.

Para Efing e Neves ${ }^{44}$ a relação médico-paciente abrange os requisitos necessários para a caracterização de uma relação de consumo, consoante os artigos $2^{\circ}$ e $3^{\circ}$ do Código de Defesa do Consumidor: um consumidor, que é o paciente; um fornecedor de serviço, que é o médico e um serviço, que pode ser a assistência médica, a consulta, a cirurgia, dependendo de cada caso. Ainda segundo o autor, esta relação merece guarida do Código de Defesa do Consumidor pelo fato da hipossuficiência e vulnerabilidade do paciente, vez que carece de conhecimento técnico e muitas vezes encontra-se com a saúde debilitada.

Viegas e Maciel $^{45}$ destacam que o Código de Defesa do Consumidor, ao cuidar da assistência médica, principalmente no que

42 MARQUES, Cláudia Lima. Contratos no Código de Defesa do Consumidor: o novo regime das relações contratuais. $4^{\mathrm{a}}$ ed. São Paulo: Revista dos Tribunais, 2004, p. 185.

43 MIRAGEM, Bruno. Direito civil: Responsabilidade Civil. São Paulo: Saraiva, 2015, p. 587.

44 EFING, Antônio Carlos; NEVES, Mariana Moreira. Consentimento livre e esclarecido: responsabilidade civil do médico pelo descumprimento do dever de informar. Revista da Faculdade de Direito da UFMG, 2015, n. 65, p. 82.

45 VIEGAS, Cláudia Mara de Almeida Rabelo; MACIEL, Renato Anatólio Lima Horta. A responsabilidade civil dos médicos e hospitais, à luz do direito consumerista. Revista do Direto Privado, v. 81. 2018. São Paulo: Revista dos Tribunais, setembro 2017, p. 40. 
concerne às relações entre o profissional da medicina e o usuário dos serviços médicos, deixa evidente a condição de consumidores dos pacientes.

Vinicius Calado ${ }^{46}$, ao ministrar proveitosa lição sobre a relação jurídica médico-paciente, afirma:

A relação jurídica privada entre o médico e o seu paciente é compreendida majoritariamente pela doutrina e pela jurisprudência como uma relação de consumo, sendo assim aplicáveis o Código de Defesa do Consumidor - CDC e o Código Civil -CC, a luz da Constituição Federal - CF, visto que em regra o médico e o paciente estão ungidos por força de uma relação obrigacional contratual, seja direta (contrato particular) ou indireta (através de um plano de saúde).

Robustecendo a assertiva do autor antes mencionado, Bruno Miragem ${ }^{47}$ afirma que a prestação de serviços médicos usualmente configura uma relação de consumo protegida pelo Código de Defesa do Consumidor e cuja boa-fé por parte dos contratantes é indispensável, sendo a informação de suma importância nesse processo.

Aprofundando-se sobre o tema, René Dotti e Laís Bergstein ${ }^{48}$ asseveram que nas relações de consumo, quando alguém manifesta de alguma forma sua vontade no sentido de contratar, o faz confiando nas informações prestadas pelo outro contratante, do que surgem legítimas expectativas que devem ser atendidas.

46 CALADO, Vinicius de Negreiros. Responsabilidade civil do médico e consentimento informado. Curitiba: Juruá, 2014, p. 31.

47 MIRAGEM, Bruno. Direto do consumidor. São Paulo: Revista dos Tribunais, 2008, p. 301.

48 DOTTI, René Ariel; Bergstein, Laís.O direito de o paciente ser ouvido: a responsabilidade civil e criminal do médico. Revista de Direito do Consumidor, vol. 111, ano 26. São Paulo: Revista dos Tribunais, maio-jun. 2017, p. 81. 
Nas palavras de Gustavo Borges ${ }^{49}$ ao lecionar sobre a relação jurídica médico-paciente:

No Código de Defesa do Consumidor, o dever de informar e esclarecer o paciente pelos profissionais da medicina decorre da positivação indicada: na regra geral, no art. 6ํㅡㄴ III; nas regras retificadoras genéricas do dever de informar, nos arts. $4^{\circ}$, IV, $8^{\circ}$, parágrafo único e 9o; nas regras de responsabilidade civil, nos arts. 12 e 14; nas regras vinculativas de informação como integrantes do contrato, nos arts. 30,31 , 36, parágrafo único, 37 e 38 e; nas regras assecuratórias do amplo conhecimento pelo consumidor do conteúdo do contrato, no art. 46. Além da boa-fé objetiva, que está presente nos arts.

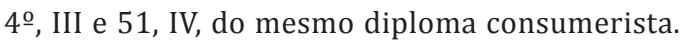

Assim sendo, pode-se dizer que a natureza da relação jurídica médico-paciente é, segundo a doutrina, predominantemente de natureza contratual e regulamentada principalmente pelo Código de Defesa do Consumidor, sendo o dever do médico de prestar todas as informações pertinentesao paciente resultante do princípio da boa-fé objetiva, apresentando-se como um desdobramento da autonomia e da dignidade da pessoa humana.

\subsection{RESPONSABILIDADE CIVIL DO MÉDICO}

Carlos Roberto Gonçalves ${ }^{50}$ assinala que a palavra responsabilidade tem sua origem na raiz latina spondeo, pela qual se vinculava o devedor, solenemente, nos contratos verbais do direito romano, tendo por finalidade restaurar o equilíbrio moral e patrimonial provocado pelo autor de um dano. A restauração

49 BORGES, Gustavo. Erro médico e a falha no dever de informação: a proteção do consumidor.Revista de Direito do Consumidor, vol. 102, ano 24. São Paulo: Revista dos Tribunais, nov. - dez. 2015, p. 461.

50 GONÇALVES, Carlos Roberto. Direito civil esquematizado. 2 ed., v.3, São Paulo: Saraiva, 2015, p. 41. 
deste equilíbrio e harmonia violados pelo dano constituem a fonte geradora da responsabilidade civil.

Lembra Rui Stoco ${ }^{51}$, acerca da responsabilidade civil:

A noção da responsabilidade pode ser haurida da própria origem da palavra, que vem do latim respondere, responder a alguma coisa, ou seja, a necessidade que existe de responsabilizar alguém pelos seus atos danosos. Essa imposição estabelecida pelo meio social regrado, através dos integrantes da sociedade humana, de impor a todos o dever de responder por seus atos, traduz a própria noção de justiça existente no grupo social estratificado. Revela-se, pois, como algo inarredável da natureza humana.

Ainda segundo o autor a ideia de responsabilidade civil parece sempre estar relacionada à noção de não prejudicar outro, podendo ser definida como a aplicação de medidas que obriguem alguém a reparar o dano causado a outrem em razão de sua ação ou omissão.

No entender de Sergio Cavalieri ${ }^{52}$, a responsabilidade civil é um dever jurídico sucessivo, que decorre da violação de uma obrigação (dever jurídico originário). 0 profissional, ao prestar um serviço, assume uma obrigação, ou seja, um dever jurídico originário, surgindo a partir daí a responsabilidade, que consiste no dever de indenizar o prejuízo causado pelo não cumprimento da obrigação. Dessa maneira, teríamos a obrigação e a sua violação como pressupostos para o surgimento da responsabilidade civil.

Assim, tem-se que o médico, ao não prestar ou prestar insuficientemente as informações ao paciente, estaria violando a sua obrigação nessa relação contratual, cabendo então sua responsabilização civil.

51 STOCO, Rui. Tratado de responsabilidade civil: Doutrina e Jurisprudência. 7 ed. São Paulo: Revista dos Tribunais, 2007, p. 114.

52 CAVALIERI FILHO, Sérgio. Programa de Responsabilidade Civil. 9 ed. São Paulo: Atlas, 2010, p. 2. 
Ao afirmar que a responsabilidade civil constitui uma espécie de sanção civil, Maria Helena Diniz ${ }^{53}$ assevera que ela decorre de uma infração a uma norma de direito privado, e é compensatória, pois abrange a reparação do dano ou uma indenização. Ainda segundo a autora, apresenta-se dessa forma a dupla função da responsabilidade civil, que é tanto garantir o direito do lesado à segurança, quanto de impor uma sanção, mediante a reparação do dano, punindo-se o seu agente causador e, com isso, desestimulando a prática de atos lesivos.

Assinala Nery Junior ${ }^{54}$ que a responsabilidade civil é a consequência da imputação civil do dano a pessoa que lhe deu causa ou que responda pela indenização correspondente, nos termos da lei ou do contrato. A indenização devida pelo responsável pode ter natureza compensatória e/ou reparatória do dano causado.

A responsabilidade civil adotada pelo Código de Defesa do Consumidor é a objetiva, ou seja, independe de culpa ou dolo. Em seus artigos 12,13, 14, 18, 19 e 20, o CDC expõe claramente essa responsabilidade objetiva, inclusive solidária, entre os fornecedores de produtos e os prestadores de serviço.

A única exceção constante na codificação é a relacionada aos profissionais liberais que prestam serviço e no qual o médico se insere, já que somente respondem mediante prova de culpa (responsabilidade subjetiva). Ela consta no parágrafo $4^{\circ}$ do art. 14 do Código de Defesa do Consumidor, conforme transcrito: "§ 4 ㅇ - A responsabilidade pessoal dos profissionais liberais será apurada mediante a verificação de culpa." ${ }^{55}$

53 DINIZ, Maria Helena. Curso de direito civil brasileiro: Responsabilidade Civil. 22. ed. São Paulo: Saraiva, 2008, vol.7, p. 8.

54 NERY JR, Nelson. NERY, Rosa Maria de Andrade. Código Civil Comentado. 10 ed. São Paulo: Revista dos Tribunais, 2013, p. 933.

55 BRASIL, Lei no 8078, de 11 de setembro de 1990. Dispõe sobre a proteção do consumidor e dá outras providências. Diário Oficial da República Federativa do Brasil, Brasília, DF, 12 set. 1990. 
Bruno Miragem ${ }^{56}$ ao lecionar sobre a culpa na responsabilidade civil médica, assinala:

A exemplo da responsabilidade civil em geral, decorre da falta, do descumprimento de um dever. Este dever, como mencionamos, é um dever genérico (cuidado, cautela), ou dever específico (diagnóstico, informação). Já no que se refere à natureza desta responsabilidade, a regra entre os profissionais liberais é a responsabilidade subjetiva (mediante verificação de culpa).

Ou seja, serão os médicos civilmente responsabilizados somente quando ficar provada qualquer modalidade de culpa: imprudência, negligência ou imperícia, a teor do estatuído no art. 951 do Código Civil, in verbis:

“O disposto nos arts. 948,949 e 950 aplica-se ainda no caso de indenização devida por aquele que, no exercício da atividade profissional, por negligência, imprudência ou imperícia, causar a morte do paciente, agravar-lhe o mal, causar-lhe lesão, ou inabilitá-lo para o trabalho".

Para Antonio Efing e Mariana Neves ${ }^{57}$, na formação desta responsabilidade (subjetiva) é necessário haver os elementos constituintes da obrigação de indenizar, os chamados pressupostos, quais sejam: a conduta do agente (ação ou omissão), a ocorrência de um dano, que pode ser tanto de caráter patrimonial como extrapatrimonial, o nexo de causalidade entre a conduta e o resultado e por fim o dolo ou culpa do agente causador do dano.

56 MIRAGEM, Bruno. Curso de direito do consumidor. São Paulo: Revista dos Tribunais, 5. ed., 2014, p. 583.

57 EFING, Antônio Carlos; NEVES, Mariana Moreira. Consentimento livre e esclarecido: responsabilidade civil do médico pelo descumprimento do dever de informar. Revista da Faculdade de Direito da UFMG, 2015, n. 65, p. 79. 
Ao lecionarem sobre os pressupostos da responsabilidade civil Gustavo Borges e Roberta Mottin ${ }^{58}$ afirmam:

A conduta se apresenta como um ato lícito ou ilícito, comissivo ou omissivo, voluntário e objetivamente imputável, do próprio agente ou de terceiro, que cause dano a outrem, gerando o dever de indenizar. Tal dever de ressarcimento decorre da culpa, ou seja, quando, diante das circunstâncias concretas, entende-se que o agente poderia ou deveria ter agido de modo diverso. Não havendo culpa, não haverá, em regra, qualquer responsabilidade. Ademais, só haverá responsabilidade civil se houver um dano a reparar, seja ele moral ou patrimonial. O terceiro pressuposto da responsabilidade civil é a relação de causalidade entre o dano e a ação que o provocou: o nexo causal. Para isso, é necessário que se verifique que o dano não ocorreria se o fato (a conduta) não tivesse acontecido.

Portanto, trata-se da responsabilidade civil subjetiva, com base na análise da culpa, resultante da atuação direta e pessoal do médico frente ao paciente e do qual resulte um dano patrimonial ou extrapatrimonial.

Em relação a necessária existência de dano para configurar responsabilidade civil do médico, aduz Rui Stoco $0^{59}$ : "Se não houve informação ao paciente ou cliente, ou essa informação foi insuficiente e precária, impedindo-o de autodeterminar-se, poderá surgir a obrigação de reparar, se ocorrer um dano[...]"

Percebe-se, pelos ensinamentos do autor, que tanto na ausência de informação, quanto nas informações incompletas, haverá

58 BORGES, Gustavo; MOTTIN, Roberta Weirich. Responsabilidade civil por ausência de consentimento informado no atendimento médico: panorama jurisprudencial do STJ. Revista de Direito Privado, vol. 64, ano 16. São Paulo: Revista dos Tribunais, out. - dez. 2015, p. 122.

59 STOCO, Rui. Tratado de responsabilidade civil. 8 ed. São Paulo: Revista dos Tribunais, 2011, p. 671. 
violação ao princípio da autonomia e ao dever ético profissional, fatos que podem ensejar a responsabilização do médico, desde que configurado o dano.

Nesse sentido pode-se citar a Apelação no 70067906073 julgada pela 10ª Câmara Cível do Tribunal de Justiça do Estado do Rio Grande do Sul (TJRS), tendo como relator o Desembargador Jorge Alberto Schreiner Pestana:

RESPONSABILIDADE CIVIL. SENTENÇA CITRA PETITA. VÍCIO. POSSIBILIDADE DE JULGAMENTO IMEDIATO. CAUSA MADURA. Constatada a omissão do juízo de $1^{\text {o }}$ grau no exame de pedidos iniciais: responsabilização dos réus a partir da violação do dever de informação pelo médico. Cabimento de o tribunal julgá-los. Causa madura. Inteligência do art. 1.013, § 3 o inc. III do CPC/2015. ERRO MÉDICO. CIRURGIA PARA RETIRADA DE CISTO NO OVÁRIO. VIDEOLAPAROSCOPIA. NEGLIGÊNCIA NO PÓS-OPERATÓRIO NÃO EVIDENCIADA. DEVER DE INDENIZAR INOCORRENTE. - A responsabilização do profissional liberal por defeito na prestação do serviço implica comprovação de culpa. art. 14, § $4^{\circ}$, do CDC. São pressupostos da responsabilidade subjetiva a comprovação da ocorrência do dano, a culpa ou dolo do agente e o nexo de causalidade entre o agir do réu e o prejuízo da parte autora. - A responsabilidade civil de hospitais e clínicas quanto aos atos dos profissionais da saúde a eles vinculados possui, igualmente, natureza subjetiva. Precedentes do STJ. - Impossibilidade de o nosocômio responder, na espécie, por atos praticados por médico que não pertence ao seu quadro de empregados. Situação em que o clinico foi escolhido dentre os vinculados ao plano de saúde da paciente. - Caso em que familiar dos autores se submeteu a cirurgia para retirada de cisto de ovário. Procedimento realizado através de videolaparoscopia. Perfuração de órgão. Situação que desencadeou morte por infecção. Probabilidade de ocorrência do evento. Tratamento no 
pós-operatório que se deu de maneira adequada. Ausência de descuido do corpo clínico em relação aos procedimentos posteriores à intervenção cirúrgica. Negligência ou Imperícia não verificada. Dever de indenizar não configurado. AUSÊNCIA DE CUMPRIMENTO DO DEVER DE INFORMAÇÃO. RESPONSABILIDADE CIVIL DO PROFISSIONAL MÉDICO. DEVER ANEXO À RELAÇÃO. - Falta de prova de o doutor haver informado à paciente os riscos da operação. Inexistência de consentimento informado, impossibilitando à enferma, ciente dos riscos e através da autonomia da vontade, optar por realizar ou não a intervenção cirúrgica. Ausente alerta quanto à possibilidade de perfuração de órgão através do procedimento aplicado - Videolaparoscopia. Responsabilidade civil do médico reconhecida. - "É fora de qualquer dúvida que o médico incorre em responsabilidade, no caso de o tratamento vir a ser ministrado sem o consentimento livre e esclarecido do doente. Pode-se afirmar que o consentimento é um pré-requisito essencial de todo tratamento ou intervenção médica" - Lição doutrinária. - Dano moral ocorrente por presunção, in re ipsa. Morte de familiar dos autores por infecção decorrente de rompimento de órgão. Violação ao dever de consentimento informado. Precedentes desta Corte. Valor da indenização que deve considerar que o erro não ocorreu na intervenção cirúrgica ou nos atos pós-operatórios, mas decorre da ausência do consentimento informado à paciente dos riscos do procedimento. Jurisprudência deste tribunal quanto ao tópico. Ausente sistema tarifado, a fixação do quantum indenizatório ao dano extrapatrimonial está adstrita ao prudente arbítrio do juiz. Valor fixado em $\mathrm{r} \$ 22.000,00$ (vinte e dois mil reais) para cada autor a ser arcado exclusivamente pelo médico réu. DERAM PROVIMENTO EM PARTE À APELAÇÃO. UNÂNIME.

(Apelação cível no 70067906073, Décima Câmara Cível, Tribunal de Justiça do RS, Relator: Jorge Alberto Schreiner Pestana, Julgado em 02/06/2016) 
Também nesse sentido:

APELAÇÃO CÍVEL. RESPONSABILIDADE CIVIL MÉDICA.AÇÃO DE INDENIZAÇÃO POR DANOS MORAIS E MATERIAIS. CIRURGIA ESTÉTICA-REPARATÓRIA. CORREÇÃO DE PTOSE PALPEBRAL CONGÊNITA. FALHA NA PRESTAÇÃO DO SERVIÇO MÉDICO. SEQUELAS TEMPORÁRIAS: BLEFARITE, CERATITE, LAGOFTALMO E DANO ESTÉTICO. NECESSIDADE DE DUAS NOVAS INTERVENÇÕES CORRETORAS. FALHA QUANTOAO DEVER DE OBTER CONSENTIMENTO INFORMADO. CONSIDERAÇÕES A RESPEITO. DEVER DE INDENIZAR. PROCEDÊNCIA DA AÇÃo. Caso envolvendo cirurgia de natureza mista, estética e reparadora, para corrigir ptose palpebral congênita (queda da pálpebra superior), a qual não resultou exitosa, pois a paciente desenvolveu ceratite, blefarite, lagoftalmo, além de impossibilidade de fechar o olho, padecendo de dores e piora da visão. Tentativa parcialmente exitosa de resolver o problema com nova cirurgia, com o mesmo médico, e necessidade de tratamento com outros médicos e nova cirurgia, ano e meio mais tarde. Do conjunto da prova produzido extraem-se elementos suficientes de convicção quanto à falha médica, pois a autora continuou apresentando os mesmos problemas que a cirurgia se propunha a corrigir, com o agravamento pelo surgimento de ceratite e blefarite, problemas esses que não estavam presentes anteriormente às intervenções e que, portanto, podem ser razoavelmente atribuíveis aos procedimentos realizados pelo réu. Nesse caso, incumbia ao réu a prova convincente ou da inexistência de tais problemas, ou de sua não derivação dos atos por ele praticados. Por outro lado, o fato de ter a autora se submetido a uma nova cirurgia, ano e meio após as intervenções do réu, para resolver os mesmos problemas, que até então persistiam, constitui evidência da inocuidade da atuação do médico réu. CONSENTIMENTO INFORMADO. Pacientes também são sujeitos de direito e não apenas ob- 
jeto de atenção médica. Cabe a eles, no exercício de sua autonomia, participar das decisões que lhe digam respeito, dando a palavra definitiva sobre os limites das atuações médicas a eles concernentes. Portanto, atualmente tem-se que o médico somente afasta sua responsabilidade pelos efeitos danosos decorrentes de uma intervenção médica, mesmo na ausência de qualquer falha técnica sua, se tiver previamente esclarecido seu paciente sobre todas as circunstâncias envolvendo o procedimento, particularmente os riscos existentes, bem como as alternativas presentes, seus custos, os efeitos de cada uma,além de outros elementos, de forma a obter o consentimento devidamente informado e esclarecido do paciente. 0 consentimento é um processo (um diálogo), uma explicação passo a passo, não uma formalidade. Portanto, não se esgota na coleta de uma assinatura do paciente em um formulário previamente redigido pelo médico. Como regra, o consentimento pode ser manifestado por qualquer forma, oral ou escrita. Igualmente a informação que o precede segue o regime da liberdade de forma. Após alguma hesitação inicial, firmou-se o entendimento de que cabe ao médico, embora réu na demanda, comprovar ter dado todas as informações pertinentes e obtido o consentimento esclarecido do paciente. Sendo ônus do médico tal prova, qualquer dúvida a respeito deve ser dirimida em favor do paciente, ou seja, supondo-se a ausência de prestação das informações necessárias. A cirurgia de que tratam os autos era de natureza mista, reparatória, mas também estética. Ora, no campo da cirurgia estética, há consenso sobre a existência de um dever redobrado de informação, por parte do médico, não só no direito pátrio, mas também no âmbito do direito comparado. Portanto, no caso concreto, a situação do réu envolvia um dever acrescido de informações (ao menos em relação à parte estética do procedimento). E esse dever, nos níveis exigidos, não foi alcançado, acarretando o dever de 
reparar os danos. SENTENÇA REFORMADA. APELO PROVIDO. (Apelação Cível № 70066171869, Nona Câmara Cível, Tribunal de Justiça do RS, Relator: Iris Helena Medeiros Nogueira, Redator: Eugênio Facchini Neto, Julgado em 25/11/2015)

Portanto, a ausência do termo de consentimento livre e esclarecido constitui evidente violação aos direitos básicos dos consumidores, consolidados nos artigos 6º inciso III, e 31 do Código de Defesa do Consumidor, in verbis:

"Art. 6 São direitos básicos do consumidor:

$[\ldots]$

III - a informação adequada e clara sobre os diferentes produtos e serviços, com especificação correta de quantidade, características, composição, qualidade e preço, bem como sobre os riscos que apresentem;

[...]."

Art. 31. A oferta e apresentação de produtos ou serviços devem assegurar informações corretas, claras, precisas, ostensivas e em língua portuguesa sobre suas características, qualidades, quantidade, composição, preço, garantia, prazos de validade e origem, entre outros dados, bem como sobre os riscos que apresentam à saúde e segurança dos consumidores.

[...

Dessa maneira, pode-se dizer que a responsabilidade civil médica por falha no dever de informar pauta-se em preceitos da Constituição Federal, da Lei 10.406/2002 (Código Civil), da Lei 8.078/1990 (Código de Defesa do Consumidor) e respectivos diplomas reguladores, como também por meio de pareceres, resoluções, portarias e decisões editadas pelos Conselhos Federal e Regionais de Medicina. A aplicação de uma ou outra legislação vai depender de que forma o serviço médico foi contratado, devendo a culpa do profissional médico obrigatoriamente ser averiguada. 


\section{PANORAMA JURISPRUDENCIAL DO TJRS}

No intuito de elaborar um panorama jurisprudencial do TJRS acerca da responsabilidade civil médica por ausência ou falha na aplicação do consentimento informado, foi realizada consulta à página do tribunal na internet, através da pesquisade jurisprudência, utilizando-se as seguintes palavras-chave: "consentimento informado", "médico" e "responsabilidade civil".

Foram encontrados 58 acórdãos que tratam sobre o tema. 0 lapso temporal da pesquisa ocorreu entre o período de novembro de 2003 e o mês de setembro de 2018.

O levantamento dos dados e a análise dos julgados possibilitou conhecer o posicionamento do Tribunal acerca do tema e em que medida considera-se adimplida a obrigação médica de informar.

Isto posto, vamos demonstrar através do gráfico 1 a evolução do número de acórdãos acerca do tema nos últimos 15 anos, para, em seguida, apresentar o gráfico 2, que demonstra a relação da existência ou ausência do consentimento informado com o dever de indenizar.

Gráfico 1 - Evolução do número de acórdãos

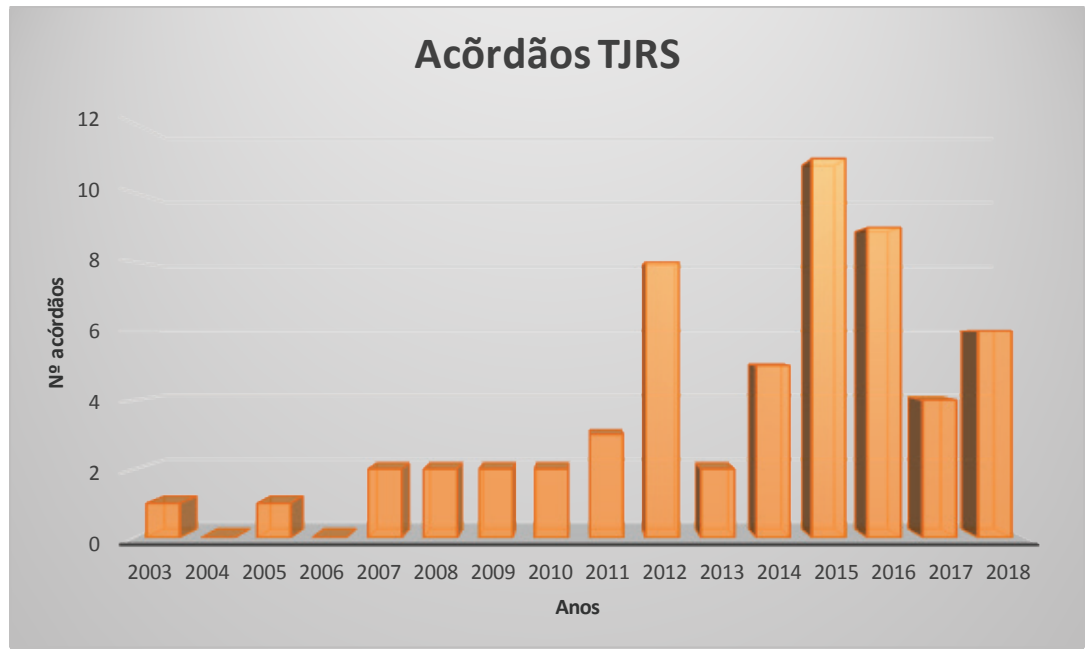

Fonte: Elaborado pelo autor. 
A análise do gráfico 1 permite afirmar que o número de acórdãos relativos a matéria responsabilidade civil do médico em função do consentimento informado tem aumentado com o decorrer dos anos. Também fica evidente que se concentram nos últimos cinco anos os acórdãos relativos ao assunto em pauta.

Gráfico 2 - Relação do consentimento informado com o dever de indenizar

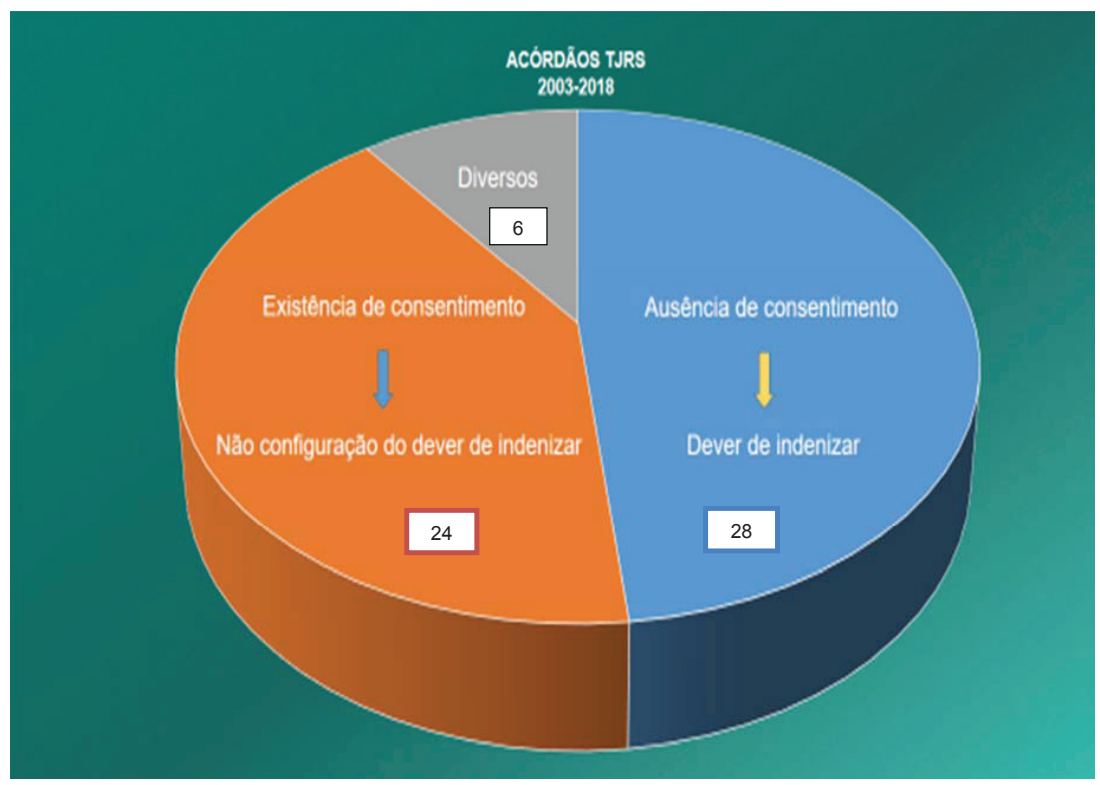

Fonte: Elaborado pelo autor.

0 gráfico 2 demonstra a relação entre a existência/ausência do consentimento com a configuração ou não do dever de indenizar. De um total de 58 acórdãos estudados, 28 acórdãos (48\%) confirmam que a ausência de consentimento por parte do paciente na prestação dos serviços médicos configura o dever de indenizar por parte do profissional da saúde.

Por outro lado, 24 acórdãos (41\%) deixam claro que a prova da existência do consentimento informado antes de um procedi- 
mento ou tratamento médico, não configura o dever de indenizar, afastando, por consequência, a responsabilidade civil do médico.

Dos 6 acórdãos restantes (10\%), dois deles entenderam que não havendo demonstração de dano patrimonial ou extrapatrimonial, a falha no dever de informar não gera obrigação de indenizar. Já em outro acórdão os desembargadores entenderam que incumbia à autora a prova quanto à existência de falha no dever de informação pelo médico, não havendo, nesse caso, obrigação de indenizar. $\mathrm{O}$ acórdão seguinte demonstrou que sem culpa do médico, a falta de consentimento não gera a obrigação de indenizar. Nesse mesmo sentido foi o próximo acórdão, quando os desembargadores decidiram que eventual ausência de autorização informada não influenciaria diretamente a decisão da paciente quanto à realização do exame. Por fim, o último acórdão destaca que em casos de risco de vida não há que se falar em consentimento prévio.

\section{CONSIDERAÇÕES FINAIS}

O Código Civil ao estabelecer que ninguém pode ser constrangido a submeter-se, com risco de vida, a tratamento médico ou a intervenção cirúrgica, deixa claro que o princípio informador da disposição legal é o da salvaguarda da dignidade da pessoa humana, conforme artigo 5oㅡ, II e III da Constituição Federal.

Desta maneira, no entender de Nery Junior ${ }^{60}$, cumpre-nos fazer uma reflexão: no choque entre os direitos fundamentais vida e liberdade contidos na Constituição Federal, a opção do legislador foi a de prestigiar a vida que corre perigo. Ou seja, a predominância do valor "vida" deve nortear a ação do médico para salvar o paciente que carece de tratamento ou intervenção imediata.

Somente nesses casos, em que o paciente corre risco de vida, o dever de informar dos médicos é substituído pela ur-

60 NERY JR, Nelson. NERY, Rosa Maria de Andrade. Código Civil Comentado. 10 ed. São Paulo: Revista dos Tribunais, 2013, p. 275. 
gência do caso, sem que o consentimento do paciente possa ser validamente tomado.

0 consentimento válido, no entender de André Pereira ${ }^{61}$, transfere para a esfera jurídica do paciente os riscos da intervenção, desde que esta seja realizada diligentemente.

Assim, na relação médico-paciente há que ser plenamente exercitado o direito à informação do paciente, com todas as informações pertinentes ao caso, percebendo-se uma clara evolução da aplicação do consentimento informado no sentido de valorizar a autonomia da vontade do paciente.

Quando o paciente recebe do médico todas as informações pertinentes e de modo adequado sobre sua enfermidade e tipos de tratamento, seu padrão de vulnerabilidade na relação médico-paciente diminui, podendo então fazer conscientemente a sua opção.

O estudo demonstrou que o consentimento informado, quando prestado de forma correta, possui o efeito de legitimar o tratamento de saúde, respeitando a autonomia da vontade, além de transferir para o paciente a responsabilidade sobre os riscos ou consequências sobre os quais foi previamente alertado.

Infelizmente, porém, ao se realizar uma análise profunda do tema, fica claro que existe uma supervalorização do dever de informação por parte dos profissionais da saúde, criando o fenômeno da medicina defensiva com o consequente e indesejado aumento da burocratização na relação médico-paciente. Esta relação, que deveria ser de parceria entre os envolvidos, na maior parte das vezes passa a ser encarada com desconfiança e atrito entre médicos e paciente.

Os médicos, ao praticarem a medicina defensiva, no intuito de se protegerem de eventuais processos judiciais por responsabilidade civil, utilizam um documento conhecido como termo de

61 PEREIRA, André Gonçalo Dias. o consentimento informado na relação médico-paciente: estudo de Direito Civil. Coimbra: Coimbra, 2004, p. 121. 
consentimento informado, que deveria possibilitar ao paciente verificar em um único documento todas as informações pertinentes ao seu caso e assim auxiliar nas decisões sobre o seu tratamento, quando o procedimento não for urgente.

No entanto, no entender de Carlos Ragazzo ${ }^{62}$, o termo de consentimento informado, na forma como está sendo aplicado pelos profissionais da saúde, que geralmente utilizam-se de formulários padrão, torna-se um instrumento que busca somente isentar o médico de responsabilidades advindas de erro médico, e não um processo que almeja informar o paciente dos possíveis riscos previstos na literatura médica, possibilitando assim a sua autodeterminação.

Portanto, de um lado, há a necessidade de o médico transmitir as informações ao paciente, mas, de outro, o instrumento dessas informações - o termo de consentimento informado - pode ser transformado em meio de defesa que, em verdade, procura isentar o médico de toda e qualquer responsabilidade.

A pesquisa nos conduziu a concluir que uma das maneiras possíveis de mitigar os danos causados pela má aplicação do processo de consentimento informado seria a de conceder ao paciente tempo suficiente antes dos procedimentos médicos a fim de maturar e eleger livremente a sua decisão.

Ante o exposto, conclui-se desejável que um lapso de tempo razoável medeie a prestação do consentimento e a intervenção, de forma a proporcionar ao paciente um tempo de reflexão, devendo ser a principal característica do consentimento informado a capacidade de refletir todo o processo comunicacional havido entre as partes, confirmando assim a verdadeira afirmação da autonomia da vontade do paciente e diminuindo os danos causados pela falta de informação, afastando, por consequência, a responsabilidade civil do médico.

62 RAGAZZO, Carlos Emanuel Jopert. 0 dever de informar dos médicos e o consentimento informado. Curitiba: Juruá, 2009, p. 127. 


\section{REFERÊNCIAS}

BARBOSA, Heloisa Helena. Responsabilidade civil em face das pesquisas em seres humanos: efeitos do consentimento livre e esclarecido. In: MARTINS-COSTA, Judith; MOLLER, Letícia Ludwig (org.). Bioética e Responsabilidade. Rio de Janeiro: Forense, 2009.

BORGES, Gustavo. Erro médico e a falha no dever de informação: a proteção do consumidor. Revista de Direito do Consumidor, vol. 102, ano 24. São Paulo: Revista dos Tribunais, nov.- dez. 2015, p. 458-465.

BORGES, Gustavo; MOTTIN, Roberta Weirich. Responsabilidade civil por ausência de consentimento informado no atendimento médico: panorama jurisprudencial do STJ. Revista de Direito Privado, vol. 64, ano 16. São Paulo: Revista dos Tribunais, out. - dez. 2015, p. 119 - 143.

BRASIL, Código Civil. Lei no 10.406, de 10 de janeiro de 2002. Institui o Código Civil. Diário Oficial da República Federativa do Brasil, Brasília, DF, 2002.

BRASIL, Constituição (1988). Diário Oficial da República Federativa do Brasil, Brasília, DF, 05 de outubro de 1988.

BRASIL, Lei no 8078, de 11 de setembro de 1990. Dispõe sobre a proteção do consumidor e dá outras providências. Diário Oficial da República Federativa do Brasil, Brasília, DF, 12 set. 1990.

CALADO, Vinicius de Negreiros. Responsabilidade civil do médico e consentimento informado. Curitiba: Juruá, 2014.

CANTALI, Fernanda Borghetti. Direitos da Personalidade - disponibilidade relativa, autonomia privada e dignidade humana. Porto Alegre: Livraria do Advogado, 2009.

CAVALIERI FILHO, Sérgio. Programa de Responsabilidade Civil. 9 ed. São Paulo: Atlas, 2010.

CAVALIERI FILHO, Sérgio. Programa de Responsabilidade Civil. 11 ed. São Paulo: Atlas, 2014.

DIAS, José de Aguiar. Da Responsabilidade Civil. Rio de Janeiro: Lumen Juris, 2012.

DINIZ, Maria Helena. Curso de direito civil brasileiro: responsabilidade civil. 22. ed. São Paulo: Saraiva, 2008, vol.7.

DOTTI, René Ariel; Bergstein, Laís. 0 direito de o paciente ser ouvido: a responsabilidade civil e criminal do médico. Revista de Direito do 
Consumidor,vol. 111, ano 26. São Paulo: Revista dos Tribunais, maiojun. 2017, p. 75-97.

EFING, Antônio Carlos; NEVES, Mariana Moreira. Consentimento livre e esclarecido: responsabilidade civil do médico pelo descumprimento do dever de informar. Revista da Faculdade de Direito da UFMG, 2015, p. 67-90.

FACCHINI NETO, Eugênio. O maior consenso possível - O consentimento informado sob o prisma do direito comparado. Revista de Direito Civil Contemporâneo, 2015, p. 953 - 1024.

FACCHINI NETO, Eugênio; EICK, Luciana Gemelli. Responsabilidade civil do médico pela falha no dever de informação, à luz do princípio da boa-fé objetiva. Revista da AJURIS, 2016, v. 42, n. 138, p. 51-86.

FERNANDES, Carolina Fernandez; PITHAN, Livia Haygert. 0 consentimento informado na assistência médica e o contrato de adesão: uma perspectiva jurídica e bioética. Revista HCPA. Porto Alegre, vol. 27, n. 2, 2007, p. 78-82.

GONÇALVES, Carlos Roberto. Direito civil esquematizado. 2 ed., vol.3, São Paulo: Saraiva, 2015.

GUSMÃO, Sebastião. História da medicina: evolução e importância. [S.l.]. 2018. Disponível em: <http://www.museu-emigrantes.org/ Hist\%C3\%B3ria-da-medicina.pdf $>$. Acesso em: 08 jan. 2018.

HOUAISS, Antônio; VILLAR, Mauro; DE MELLO FRANCO, Francisco Manoel. Dicionário Houaiss da Língua Portuguesa. 2001.

LÔBO, Paulo Luiz Netto. A informação como direito fundamental do consumidor. Revista de Direito do Consumidor, no 37, jan.- mar. 2001, p. $59-76$.

MARQUES, Cláudia Lima. Contratos no Código de Defesa do Consumidor: o novo regime das relações contratuais. 4 ed. São Paulo: Revista dos Tribunais, 2004.

MIRAGEM, Bruno. Curso de Direito do Consumidor. São Paulo: Revista dos Tribunais, 5 ed., 2014.

MIRAGEM, Bruno. Direto do Consumidor. São Paulo: Revista dos Tribunais, 2008.

MIRAGEM, Bruno. Direito civil: Responsabilidade Civil. São Paulo: Saraiva, 2015. 
MIRANDA, Pontes de. Tratado de Direito Privado. Rio de Janeiro: Borsoi, 1966. T. LIII.

NERY JR, Nelson. NERY, Rosa Maria de Andrade. Código Civil Comentado. 10 ed. São Paulo: Revista dos Tribunais, 2013.

PEREIRA, André Gonçalo Dias. 0 consentimento informado na relação médico-paciente: estudo de Direito Civil. Coimbra: Coimbra, 2004.

PITHAN, Lívia Haygert. 0 consentimento informado no Poder Judiciário Brasileiro. Porto Alegre: Revista da AMRIGS, jan.- mar. 2012, p. 87-92.

RAGAZZO, Carlos Emanuel Jopert. 0 dever de informar dos médicos e o consentimento informado. Curitiba: Juruá, 2009.

ROBERTO, Luciana Mendes Pereira. Responsabilidade Civil do Profissional de Saúde e Consentimento Informado. Curitiba: Juruá, 2008.

SANSEVERINO, Paulo de Tarso. Responsabilidade civil no Código do Consumidor e a defesa do fornecedor. São Paulo: Saraiva, 2010.

SILVA, Carlos Alberto. 0 consentimento informado e a responsabilidade civil do médico. Revista do Tribunal Regional Federal 1aㅡ Região, Brasília, v. 15 , n. 5 , maio 2003 , p. $29-43$.

STOCO, Rui. Tratado de responsabilidade civil: doutrina e jurisprudência. 7 ed., São Paulo: Editora Revista dos Tribunais, 2007.

STOCO, Rui. Tratado de responsabilidade civil. 8 ed. São Paulo: Editora Revista dos Tribunais, 2011.

VIEGAS, Cláudia Mara de Almeida Rabelo; MACIEL, Renato Anatólio Lima Horta. A responsabilidade civil dos médicos e hospitais, à luz do direito consumerista. Revista de Direito Privado. São Paulo: Revista dos Tribunais, setembro 2017, vol. 81, ano 18, p.39-66.

VIEIRA, Jair Lot. Código de Ética Médica. 3 ed. Rio de Janeiro: edipro, 2014. 